\title{
ТРЕБОВАНИЯ, ПРЕДЪЯВЛЯЕМЫЕ К ГРАЖДАНАМ ПРИ ПОСТУПЛЕНИИ НА ВОЕННУЮ СЛУЖБУ В ОРГАНЫ ФЕДЕРАЛЬНОЙ СЛУЖБЫ БЕЗОПАСНОСТИ
}

Аннотация: Предмет: составляют правовые нормы, включая положения Конституции Российской Федерации, федерального и ведомственного законодательства, регулирующего поступление граждан на военную службу по контракту; требования, предъявляемые к гражданам при поступлении на военную службу по контракту в военную организацию государства в целом и в органы федеральной службы безопасности в частности. Особый интерес представляют нормы, предусмотренные статьей 27.1 Федерального закона «О статусе военнослужащих», статьями 16, 16.1, 16.2 Федерального закона «О федеральной службе безопасности», Федеральным законом «О противодействии коррупции», а также Федерального закона «О внесении изменений в статьи 6, 30 Федерального закона «О гражданстве Российской Федерации» и отдельные законодательнье акты Российской Федерации». Методы исследования: общенаучные (анализ, синтез, обобщение, системно-структурный метод, абстрагирование, моделирование); частнонаучные (формально-юридический, сравнительно-правовой). Научная новизна данной статьи очевидна, поскольку за последние пять лет российское законодательство относительно требований, предъявляемьх к гражданам, поступающим на военную службу по контракту и в военную организаџию государства, и органь федеральной службы безопасности, значительно дополнено и изменено. Автором был проведен анализ требований, ограничений и запретов, предусмотренных федеральным законодательством, в отношении граждан, поступающих на военную службу по контракту, и предложена классификация данных требований по группам, что, несомненно, способствует совериенствованию правового регулирования поступления граждан на военную службу по контракту. Abstract: The object of studies involves legal norms, including provisions of the Constitution of the Russian Federation, federal and departmental legislation regarding persons joining contractual military service, requirements to persons joining contractual military service in general and service in the federal security service in particular. Special attention is paid to he norms provided for by the Art. 27.1 of the Federal Law "On the Status of Military Personnel”, art. 16, 16.1, 16.2 of the Federal Law "On Federal Security Service”, Federal Law "On Fighting Corruption”, Federal Law "On Amendments to Art. 6,30 of the Federal Law "On Citizenship in the Russian Federation" and Certain Legislative Acts of the Russian Federation”. The process of studies involved general scientific methods (analysis, synthesis, generalization, systemic structural, abstraction, modeling), some specific scientific methods (formal legal, comparative legal). Scientific novelty of the article is obvious since in latest 5 years the Russian legislation regarding requirements to persons joining contractual military service in military and federal security bodies was significantly amended and changed. The author analyzed the requirements, limitations and prohibitions provided by the federal law regarding persons joining contractual military service, and she provided classification of these requirements, which shall facilitate improvement of legal regulation in the sphere of citizens joining contractual military service.

Ключевые слова: Требования к кандидатам, сотрудник органов безопасности, военная служба, поступление, ФСБ России, высококвалифицированный кадровый состав, кадровая политика, кандидат, классификация требований, военнослужаший.

Keywords: Requirements to candidates, security service staff, military service, entering, the FSS of Russia, highly qualified cadres, cadres policy, candidate, classification of requirements, military officer.

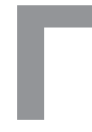

осударственная кадровая политика направлена на формирование высококвалифицированных специалистов федеральных органов исполнительной власти. Формированию высококвалифицированного кадрового состава государственной (в том числе военной) службы, на наш взгляд, может способствовать поиск лиц, отвечающих самым высоким требованиям. В связи с этим, на повестку дня выносится вопрос со- ответствия граждан требованиям, предъявляемым при поступлении на военную службу в федеральный орган исполнительной власти в области обеспечения безопасности - Федеральную службу безопасности Российской Федерации (далее - ФСБ России).

Анализ правового регулирования поступления граждан на военную службу позволяет установить, что гражданам для поступления на военную службу 


\section{Право и политика $8(176) \cdot 2014$}

по контракту в военную организацию государства в целом, в органы федеральной службы безопасности (далее- органы безопасности) в частности, необходимо соответствовать требованиям, установленным федеральным законодательством ${ }^{1}$.

Исследованию требований, предъявляемых к гражданам при поступлении на военную службу, посвятили свои работы многие учение.

А.Т. Вахидов ${ }^{2}$ под условиями поступления граждан на военную службу по контракту понимает, предусмотренные действующим законодательством обстоятельства, при которых такое поступление становится возможным. К последним относит: гражданство, достижение определенного возраста, годность по состоянию здоровья, морально-психологические качества, уровень образования и профессиональной подготовки.

О.Ю. Чижикова ${ }^{3}$, рассмотрев требования, предъявляемые к гражданам, поступающим на военную службу в пограничные органы федеральной службы безопасности, отмечает, что все группы требований урегулированы нормами права, однако не имеют строгой классификации. Автор предлагает разделить все требования, предъявляемые к гражданам, поступающим на военную службу на следующие группы:

- требования, установленные федеральным законодательством, регулирующие поступление граждан на военную службу общего характера: гражданство, образование, здоровье и уровень физического развития, наличие определенных качеств;

- требования, установленные федеральным законодательством, регулирующие поступление граждан на военную службу в пограничные органы специального характера: допуск к сведениям, составляющим государственную тайну, дактилоскопическая регистрация, профессионально-психологический отбор, прохождение испытательного срока.

Исследование требований к гражданам, поступающим на военную службу по контракту в

\footnotetext{
${ }^{1} \mathrm{O}$ воинской обязанности и военной службе : федер. закон от 28 марта 1998 года № 53-Ф3 : принят Гос. Думой 6 марта 1998 г.: одобр. Советом Федерации 12 марта 1998 г. : в ред. федер. закона от 28 ноября 2009 г. № 286-Ф3 : п. 4 ст. 33 // Собр. законодательства Рос. Федерации. - 1998. - № 13. - Ст. 1475.

2 Вахидов A.T. Организационно-правовые основы поступления граждан на военную службу по контракту в Вооруженных Силах Российской Федерации : дис. ...канд. юрид. наук. - М.: ВУ, 1996. - C. 48.

3 Чижикова О.Ю. Правовое регулирование поступления граждан на военную службу в пограничные органы федеральной службу безопасности : дис. ...канд. юрид. наук. - М.: Академия Управления МВД России, 2009. - С. 77-78.
}

военную организацию государства и в органы безопасности, позволит согласиться или опровергнуть мнения ученых.

Необходимость такого исследования обусловлена: во-первых, изменением российского законодательства, в частности, дополнением статьей 27.1 Федерального закона «О статусе военнослужащих» (в ред. Федерального закона от 25 декабря 2008 № 280$\Phi 3)^{4}$, принятием Федерального закона «О противодействии коррупции» ${ }^{5}$, внесением изменений в статьи 16, 16.1 и дополнением статьей 16.2 Федерального закона «О федеральной службе безопасности» (в ред. Федерального закона от 18 июля 2011 г. № 241-Ф3) также вступлением в силу Федерального закона «О внесении изменений в статьи 6, 30 Федерального закона «О гражданстве Российской Федерации» и отдельные законодательные акты Российской Федерации»;

во-вторых, объединением требований, предъявляемых к гражданам при поступлении на военную службу в органы безопасности, в группы и их классификацией;

в-третьих, совершенствованием правового регулирования поступления граждан на военную службу в органы безопасности.

В соответствии со статьей 33 Федерального закона от 28 марта 1998 г. № 53-Ф3 «О воинской обязанности и военной службе» ${ }^{8}$ установлены требования к гражданам, поступающим на военную службу по контракту. К данным требованиям относятся:

1. владение государственным языком Российской Федерации;

\footnotetext{
${ }^{4}$ О статусе военнослужащих : федер. закон от 27 мая 1998 г. № 76-Ф3 : принят Гос. Думой 6 марта 1998 г. : одобр. Сов. Федерации от 12 марта 1998 г. // Собр. законодательства Рос. Федерации. - 1998. - № 22. - Ст. 2331.

${ }^{5}$ О противодействии коррупции : федер. закон от 25 декабря 2008 г. № 273-Ф3 : принят Гос. Думой от 19 декабря 2008 г. : одобр. Сов. Федерации 22 декабря 2008 г. : по состоянию на 28 декабря 2013 г. // Собр. законодательства Рос. Федерации. - 2008. - № 52 (ч.1). - Ст. 6228.

${ }^{6}$ О федеральной службе безопасности : федер. закон от 3 апреля 1995 г. № 40-Ф3 : принят Гос. Думой 22 февраля 1995 г. : по состоянию на 23 июня 2014 г. // Собр. законодательства Рос. Федерации. - 1995. - № 15. - Ст. 1269.

${ }^{7}$ О внесении изменений в статьи 6 и 30 Федерального закона «О гражданстве Российской Федерации» и отдельные законодательные акты Российской Федерации : федер. закон от 4 июня 2014 г. № 142-Ф3 : принят Гос. Думой 23 мая 2014 г. : одобрен Сов. Федерации 28 мая 2014 г. // Собр. законодательства Рос. Федерации. - 2014. - № 23. - Ст. 2927.

${ }^{8} \mathrm{O}$ воинской обязанности и военной службе : федер. закон от 28 марта 1998 г. № 53-Ф3 // Собр. законодательства Рос. Федерации. - 1998. - № 13. - Ст. 1475.
} 
2. соответствие установленным медицинским и профессионально-психологическим требованиям;

3. соответствие требованиям по уровню образования, квалификации, физической подготовки.

Требования, перечисленные в пунктах 2-3, устанавливаются Министром обороны России или руководителем федерального органа исполнительной власти, в котором федеральным законом предусмотрена военная служба9.

Статья 33 указанного закона посвящена требованиям, предъявляемым к гражданам при поступлении на военную службу по контракту, однако список данных требований не полный. Законодательство, регулирующее поступление граждан на военную службу, содержит ряд отсылочных правовых норм, без соответствия которым, поступление на военную службу становится невозможным.

Проанализировав нормы федерального законодательства о поступлении граждан на военную службу по контракту в военную организацию государства, нами были выявлены следующие требования к кандидатам на военную службу.

Во-первых, добровольное заключение контракта о прохождении военной службы. Конституция Российской Федерации устанавливает, что гражданин Российской Федерации несет военную службу в соответствии с федеральным законом ${ }^{10}$, которым является Федеральный закон «О воинской обязанности и военной службе». Статьей 32 указанного закона, а также статьей 4 Положения о порядке прохождения военной службы ${ }^{11}$ устанавливается в качестве требования к гражданам, поступающим на военную службу, добровольность при заключении контракта о прохождении военной службы.

Во-вторых, требование о гражданстве. В соответствии с Федеральным законом от 28 марта 1998 г. № 53-ФЗ контракт о прохождении военной службы заключается между гражданином (иностранным гражданином) и от имени Российской Федерации Министерством обороны Российской Федерации или федеральным органом исполнительной власти, в котором федеральным законом предусмотрена военная

\footnotetext{
${ }^{9} \mathrm{O}$ воинской обязанности и военной службе : федер. закон от 28 марта 1998 г. № 53-Ф3 : п. 5 ст. 33 // Собр. законодательства Рос. Федерации. - 1998. - № 13. - Ст. 1475.

${ }^{10}$ Конституция Российской Федерации : принята на всенародном голосовании 12 декабря 1993 г. : ч. 2 ст. 59 // Российская газета. - 1993. - 25 декабря.

${ }^{11}$ Вопросы прохождения военной службы : указ Президента Российской Федерации от 16 сентября 1999 г. № 1237 // Собр. законодательства Рос. Федерации. - 1999. - № 38. - Ст. 4534.
}

служба. На военную службу по контракту поступают, как граждане Российской Федерации, так и иностранные граждане, в случаях предусмотренных федеральным законом. В отношении граждан Российской Федерации законодательством установлено дополнительное требование по подаче в соответствующий территориальный орган ФМС России уведомления о наличии у гражданина Российской Федерации гражданства (подданства) иностранного государства либо вида на жительство или иного действительного документа, подтверждающего право на его постоянное проживание в иностранном государстве (далее - второго гражданства) $)^{12}$. Федеральный закон от 4 июня 2014 г. № 142-ФЗ устанавливает порядок и сроки подачи уведомления о втором гражданстве, а также уголовную ответственность за неисполнение обязанности по подаче уведомления и административную - за нарушение установленного порядка подачи уведомления о втором гражданстве. Данное требование распространяется и на граждан Российской Федерации, поступающих на военную службу.

В-третьих, требованием к гражданам, поступающим на военную службу по контракту, является достижение определенного возраста. Частью 2 статьи 34 Федерального закона от 28 марта 1998 г. № 53-Ф3 устанавливается возраст для заключения первого контракта, а, значит, и поступления на военную службу по контракту - с 18 до 40 лет. В случае, если гражданин не достиг или уже превысил установленный возраст, он не может поступить на военную службу по контракту.

В-четвертых, статьей 34.1 указанного закона предусматривается применение испытания при поступлении на военную службу по контракту на воинские должности, подлежащие замещению солдатами, матросами, сержантами и старшинами (за исключением обучающихся в военных образовательных учреждениях профессионального образования). Целью испытательного срока является проверка кандидатов на их соответствие требованиям федеральных законов, общевоинских уставов и иных нормативных правовых актов Российской Федерации, определяющих общие, должностные и специальные обязанности военнослужащих. В соответствии с п. «е» ч. 2 ст. 51 Федерального закона «О воинской обязанности

\footnotetext{
12 О внесении изменений в статьи 6 и 30 Федерального закона «О гражданстве Российской Федерации» и отдельные законодательные акты Российской Федерации : федер. закон от 4 июня 2014 г. : принят Гос. Думой 23 мая 2014 г. : одобрен Сов. Федерации 28 мая 2014 г. // Собр. законодательства Рос. Федерации. - 2014. - № 23. - Ст. 2927.
} 


\section{Право и политика $8(176) \cdot 2014$}

и военной службе» предусмотрено специальное основание досрочного увольнения с военной службы: «как не выдержавших испытание».

В-пятых, в соответствии со ст. 34 Федерального закона «О воинской обязанности и военной службе» и ст. 4 Положения о порядке прохождения военной службы: «Контракт не может быть заключен с гражданином, в отношении которого вынесен обвинительный приговор и которому назначено наказание, в отношении которого ведется дознание либо предварительное следствие или уголовное дело в отношении которого передано в суд, имеющим неснятую или непогашенную судимость за совершение преступления, а также отбывавшим наказание в виде лишения свободы».

В-шестых, требование об обязательной государственной дактилоскопической регистрации. В соответствии со статьей 9 Федерального закона от 25 июля

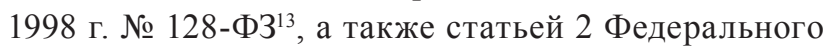
закона от 28 марта 1998 г. № 53-Ф3: «Граждане (иностранные граждане), проходящие военную службу, подлежат обязательной государственной дактилоскопической регистрации». Прохождению военной службы предшествует поступление граждан на военную службу, представляется, что такая дактилоскопическая регистрация должна осуществляться при поступлении на военную службу, а отказ лица от этой процедуры будет являться основанием в отказе заключения контракта о прохождении военной службы. Соответственно, обязательную дактилоскопическую регистрацию также можно отнести к требованию для граждан, поступающих на военную службу по контракту.

В-седьмых, требование об оформлении допуска к сведениям, составляющим государственную тайну. Положением о порядке прохождения военной службы установлено, что кандидат на военную службу в необходимых случаях в установленном порядке проходит процедуру оформления допуска к сведениям, составляющим государственную тайну14. Перечень воинских должностей, при назначении на которые гражданам оформляется допуск к государственной тайне, определяется номенклатурой должностей. В

\footnotetext{
${ }^{13} \mathrm{O}$ государственной дактилоскопической регистрации в Российской Федерации : федер. закон от 25 июля 1998 г. № 128-ФЗ: принят Гос. Думой 3 июля 1998 г. : одобр. Сов. Федерации 9 июля 1998 г.: по состоянию на 4 июня 2014 г. // Собр. законодательства Рос. Федерации. - 1998. - № 31. - Ст. 3806.

${ }^{14}$ Вопросы прохождения военной службы: указ Президента Российской Федерации от 16 сентября 1999 г. № 1237: ст. 5 // Собр. законодательства Рос. Федерации. - 1999. - № 39. - Ст. 4590.
}

номенклатуру должностей включаются только те должности, по которым допуск к государственной тайне действительно необходим для выполнения должностных (специальных, функциональных) обязанностей ${ }^{15}$. Так, данное требование к гражданам, поступающим на военную службу по контракту, не всегда имеет место при поступлении на военную службу.

Со вступлением в силу Федерального закона от 25 декабря 2008 г. № 280-Ф3 ${ }^{16}$ к военнослужащим предъявляются ограничения, запреты и обязанности, установленные в связи с ратификацией Конвенции Организации Объединенных Наций против коррупции от 31 октября 2003 г., Конвенции об уголовной ответственности за коррупцию от 27 января 1999 г. и принятием Федерального закона «О противодействии коррупции» (далее - антикоррупционное законодательство). Данные требования относительно граждан, поступающих на военную службу, мы предлагаем именовать «требованиями антикоррупционного законодательства», к которым относятся:

1. ограничения в связи с реализацией права на труд, установленные пунктом 7 статьи 10 Федерального закона «О статусе военнослужащих»;

2. ограничения, запреты и обязанности, установленные статьями 7.1, 8, 9, 11, 11.1, 12.1, 12.3 Федерального закона «О противодействии коррупции»;

3. ограничения, запреты и обязанности, установленные статьями 17, 18, 20 Федерального закона «О государственной гражданской службе».

В соответствии со ст. 16 Федерального закона «О государственной гражданской службе» ${ }^{17}$ гражданин не может быть принят на гражданскую службу, а гражданский служащий не может находиться на гражданской службе в случае: наличия близкого родства или свойства (родители, супруги, дети, братья, сестры, а также

\footnotetext{
${ }^{15}$ Об утверждении Инструкции о порядке допуска должностных лиц и граждан Российской Федерации к государственной тайне : постановление Правительства Российской Федерации от 6 февраля 2010 г. № 63 // Собр. законодательства Рос. Федерации. - 2010. № $7 .-$ Ст.762.

${ }^{16}$ О внесении изменений в отдельные законодательные акты Российской Федерации в связи с ратификацией Конвенции ООН против коррупции от 31 октября 2003 г. и Конвенции об уголовной ответственности за коррупцию от 27 января 1999 г. и принятием Федерального закона «О противодействии коррупции» : федер. закон от 25 декабря 2008 г. № 280-ФЗ : принят Гос. Думой 19 декабря 2008 г. : одобр. Сов. Федерации 22 декабря 2008 г. // Собр. законодательства Рос. Федерации. - 2008. - № 52 (ч.1). - Ст. 6235.

${ }^{17}$ О государственной гражданской службе Российской Федерации : федер. закон от 27 июля 2004 г. № 79-Ф3 // Собр. законодательства Рос. Федерации. - 2004. - № 31. - Ст. 3215.
} 
братья, сестры, родители, дети супругов и супруги детей) с гражданским служащим, если замещение должности гражданской службы связано с непосредственной подчиненностью или подконтрольностью одного из них другому. Несколько иная формулировка устанавливается пп. «з» п. 10 ст. 11 Положения о порядке прохождения военной службы: при назначении на воинские должности соблюдается следующее условие - военнослужащим, состоящим между собой в близком родстве, не разрешается проходить военную службу в одной воинской части, если один из них непосредственно подчинен или непосредственно подконтролен другому. Представляется, что в данное условие может рассматриваться, как ограничение при поступлении на военную службу (далее - ограничение в случае близкого родства).

Таким образом, гражданам для поступления на военную службу по контракту в военную организацию государства необходимо соответствовать требованиям относительно: гражданства; достижения определенного возраста; добровольного заключения контракта о прохождении военной службы; прохождения испытательного срока, дактилоскопической регистрации; отсутствия судимости; а также требованиям, установленным статьей 33 Федерального закона «О воинской обязанности и военной службе».

Мы согласны с мнением О.Ю. Чижиковой ${ }^{18}$, и вышеперечисленные требования к гражданам, поступающим на военную службу в военную организацию государства совместно с требованиями антикоррупционного законодательства, отнесем к требованиям общего характера, за исключением требования об оформлении допуска к сведениям, составляющим государственную тайну.

Говоря о поступлении на военную службу в органы ФСБ России, к военнослужащим органов безопасности предъявляются требования, как для всех военнослужащих военной организации государства, так и дополнительные требования, обусловленные спецификой прохождения военной службы в органах безопасности ${ }^{19}$.

В соответствии с этим, возникает насущная необходимость анализа требований, предъявляемых к гражданам при поступлении на военную службу в органы безопасности.

На основании требований статьи 16 Федерального закона от 3 апреля 1995 г. № 40-Ф3 к со-

\footnotetext{
18 Чижикова О.Ю. Указ. соч. - С. 77.
}

${ }^{19} \mathrm{O}$ федеральной службе безопасности : федер. закон от 3 апреля 1995 г. № 40-Ф3 : принят Гос. Думой 22 февраля 1995 г. : ст. 16.1// Собр. законодательства Рос. Федерации. - 1995. - № 15. - Ст. 1569. труднику органов безопасности предъявляются следующие требования:

1) отсутствие гражданства или подданства иностранного государства. Под этим требованием понимается наличие только гражданства нашей страны. Гражданство Российской Федерации - обязательное условие для прохождения военной службы в органах безопасности (в отличие от Вооруженных Сил Российской Федерации). Под гражданством, законодательством понимается, устойчивая правовая связь лица с Российской Федерацией, выражающаяся в совокупности их взаимных прав и обязанностей ${ }^{20}$;

2) достижение определенного возраста. Для поступления на военную службу в органы безопасности необходимо достигнуть определенного возраста. Нормами Федерального закона от 28 марта 1998 г. № 53-ФЗ устанавливается возрастной промежуток поступления на военную службу по контракту - с 18 до 40 лет, однако в соответствии со статьей 16 Федерального закона от 3 апреля 1995 г. № 40-Ф3 с гражданами Российской Федерации, являющимися высококвалифицированными специалистами, достигшими возраста 40 лет, может быть заключен первый контракт о прохождении военной службы в порядке, предусмотренным приказом Федеральной службы безопасности Российской Федерации от 27 июля 2009 г. № $357^{21}$;

3) наличие соответствующих личных, профессиональных и психологических качеств. Качества граждан, поступающих на военную службу, имеют особое значение, говоря, прежде всего, об имидже сотрудника органов безопасности.

Так, требования, предъявляемые к личным качествам граждан, поступающим на военную службу в органы безопасности, определяются должностными обязанностями, предусмотренными воинской должностью, на которую предполагается назначение кандидата, а также целями и задачами, стоящими перед структурным подразделением органа безопасности. Представляется, что такие требования должны закрепляться в должностных регламентах к конкретной воинской должности, и, исходя из личных и деловых качеств, должен осуществляться поиск талантливых

\footnotetext{
${ }^{20}$ О гражданстве Российской Федерации : федер. закон от 31 мая 2002 г. № 62-Ф3 : принят Гос. Думой 19 апреля 2002 г. : одобр. Сов. Федерации от 15 мая 2002 г. // Собр. законодательства Рос. Федерации. - 2002. - № 22. - Ст. 2031.

${ }^{21}$ Об утверждении Инструкции о порядке заключения в органах федеральной службы безопасности контрактов о прохождении военной службы с отдельными категориями граждан Российской Федерации : приказ ФСБ России от 27 июля 2009 г. № 357 // Российская газета. - 2009. - № 176. - 18 сентября.
} 
DOI: $10.7256 / 1811-9018.2014 .8 .12547$

При цитировании этой статьи сноска на dоі обязательна

\section{Право и политика $8(176) \cdot 2014$}

и перспективных граждан для военной службы в органах безопасности.

В соответствии со ст. 5 Положения о порядке прохождения военной службы и приказом Федеральной службы безопасности Российской Федерации от 13 апреля 2011 г. № $151^{22}$ устанавливается порядок организации и проведения в органах безопасности мероприятий по профессиональному психологическому отбору; требования, предъявляемые к гражданам, поступающим на военную службу; порядок определения профессиональной пригодности к военной службе, в том числе посредством проведения психофизиологического исследования.

В процессе профессионального психологического отбора проводится комплекс мероприятий по определению профессиональной пригодности граждан, поступающих на военную службу в органы безопасности. При определении профессиональной пригодности оценивается уровень развития индивидуальных психологических и психофизиологических качеств, необходимых для достижения приемлемых показателей в конкретной профессиональной деятельности, и склонность человека к данному виду деятельности. Так, определение соответствия профессиональных и психологических качеств кандидата на военную службу в органы безопасности осуществляется специалистами профессионального психологического отбора органов безопасности.

4) соответствие квалификационным требованиям к профессиональным знаниям и навыкам. На сегодняшний день приказом Федеральной службы безопасности Российской Федерации от 5 апреля 2010 г. № $159^{23}$ утверждены квалификационные требования к профессиональным знаниям и навыкам, необходимым для исполнения должностных обязанностей сотрудниками органов безопасности. Перечень знаний и навыков зависит от того, на какую должность поступает кандидат.

5) соответствие установленным медицинским требованиям по состоянию здоровья. Определение годно-

\footnotetext{
${ }^{22}$ Об утверждении Инструкции по организации и проведению профессионального психологического отбора в органах федеральной службы безопасности : приказ ФСБ России от 13 апреля 2011 г. № 151 // Бюллетень нормативных актов федеральных органов исполнительной власти. - 2011. - № 28.

${ }^{23}$ Об утверждении Квалификационных требований к профессиональным знаниям и навыкам, необходимым для исполнения должностных обязанностей военнослужащими и федеральными государственными гражданскими служащими органов федеральной службы безопасности : приказ ФСБ России от 5 апреля 2010 г. № 159 // Бюллетень нормативных актов федеральных органов исполнительной власти. - 2010. - № 19.
}

сти к военной службе по состоянию здоровья в органах безопасности осуществляется посредством медицинского освидетельствования. В соответствии с приказом Федеральной службы безопасности Российской Федерации от 29 июня 2004 г. № $457^{24}$ под медицинским освидетельствованием понимается изучение и оценка состояния здоровья и физического развития граждан на момент освидетельствования с целью определения их годности к военной службе в органах безопасности.

В соответствии с тем, что руководитель федерального органа исполнительной власти в области обеспечения безопасности устанавливает требования, предьявляемые к гражданам, поступающим на военную службу в органы безопасности ${ }^{25}$, приказом Федеральной службы безопасности Российской Федерации от 31 декабря 1999 г. № $714^{26}$ такие требования установлены относительно: уровня образования, профессиональной и физической подготовки.

В связи с внесением изменений в статью 16 Федерального закона от 3 апреля 1995 г. № 40-ФЗ нормами права предусмотрены дополнительные требования в отношении граждан, поступающих на военную службу в органы безопасности (в ред. Федерального закона от 18 июля 2011 г. № 241-Ф3).

В соответствии с ограничениями, запретами и обязанностями, установленными данной статьей, граждане Российской Федерации не могут быть приняты на военную службу в органы безопасности в случае:

a) наличия вида на жительство или иного документа, подтверждающего право на постоянное проживание на территории иностранного государства;

б) отказа от прохождения обязательной государственной дактилоскопической регистрации, процедуры проверки или оформления допуска к сведениям, составляющим государственную тайну, обязательного опроса с использованием технических и иных средств, не наносящих ущерба жизни и здоровью людей и не причиняющих вреда окружающей среде, обязательного

\footnotetext{
${ }^{24}$ Об организации военно-врачебной экспертизы в органах федеральной службы безопасности : приказ ФСБ России от 29 июня 2004 г. № 457 // Российская газета. - 2004. - № 206. - 21 сентября.

${ }^{25} \mathrm{O}$ воинской обязанности и военной службе : федер. закон от 28 марта 1998 г. № 53-Ф3 : п. 5 ст. 33 // Собр. законодательства Рос. Федерации. - 1998. - 13. - Ст. 1475; Вопросы прохождения военной службы : указ Президента Российской Федерации от 16 сентября 1999 г. № 1237 : п. 12 ст. 5 // Собр. законодательства Рос. Федерации. - 1999. - № 39. - Ст. 4590.

${ }^{26} \mathrm{O}$ требованиях, предъявляемых к гражданам, поступающим на военную службу по контракту в органы федеральной службы безопасности : приказ ФСБ России от 31 декабря 1999 года № 714 // Российская газета - 2000. - № 33.
} 
обследования на предмет употребления наркотических средств и психотропных веществ;

в) наличия судимости в настоящее время или в прошлом, в том числе снятой или погашенной, если в отношении их прекращено уголовное преследование за истечением срока давности, в связи с примирением сторон, вследствие акта об амнистии или в связи с деятельным раскаянием;

г) непредставления документов или сведений, подлежащих обязательному представлению в соответствии с нормативными правовыми актами Российской Федерации и нормативными правовыми актами федерального органа исполнительной власти в области обеспечения безопасности, либо представления подложных документов или заведомо ложных сведений;

д) наличия зарегистрированного за пределами Российской Федерации права собственности на имущество, если это не обусловлено решением задач оперативно-служебной деятельности;

е) если они являются членами политических партий и иных общественных объединений, преследующих политические цели, и (или) участвуют в их деятельности;

ж) принимать меры по отчуждению имущества, зарегистрированного за пределами Российской Федерации.

Федеральный закон «О федеральной службе безопасности» был также дополнен статьей 16.2 «Меры обеспечения собственной безопасности органов федеральной службы безопасности» ${ }^{27}$. В связи с этими дополнениями, гражданам, поступающим на военную службу в органы безопасности, необходимо проходить (далее-требования в связи с обеспечением собственной безопасности):

а) психофизиологические исследования, тестирования на предмет употребления наркотических средств и психотропных веществ, наличия у них алкогольной, наркотической или иной токсической зависимости, проверку в целях определения их пригодности к службе (работе) в органах безопасности и соответствия квалификационным требованиям, в том числе обязательный опрос с использованием технических и иных средств, не наносящих ущерба жизни и здоровью людей и не причиняющих вреда окружающей среде;

б) процедуру оформления допуска к сведениям, составляющим государственную тайну;

в) проверку, которая связана с обеспечением собственной безопасности органов безопасности, в том

\footnotetext{
${ }^{27} \mathrm{O}$ федеральной службы безопасности : федер. закон от 3 апреля 1995 г. № 40-Ф3 // Собр. законодательства Рос. Федерации. - 1995. - № 15. - Ст. 1269.
}

числе с использованием технических и иных средств, не наносящих ущерба жизни и здоровью людей и не причиняющих вреда окружающей среде.

Граждане Российской Федерации, поступающие на военную службу в органы безопасности, обязаны представлять в подразделения кадров информацию, относящуюся к обеспечению собственной безопасности органов безопасности. Порядок и сроки предоставления такой информации определены приказом Федеральной службы безопасности Российской Федерации от 6 июля 2012 г. № $335^{28}$.

Нами выявлено, что для поступления на военную службу в органы безопасности гражданам Российской Федерации необходимо соблюдать требования и ограничения, не нарушать запреты и исполнять обязанности, предусмотренные нормами федерального законодательства. Исходя из этого, мы поддерживаем мнение А.Т. Вахидова, который в отношении граждан, поступающих на военную службу, употребляет термин «условия поступления на военную службу», поскольку последние могут включать в себя помимо требований к кандидатам на военную службу, еще ограничения и запреты.

Таким образом, в связи с изменением российского законодательства, количество требований, предъявляемых к гражданам на военную службу в органы безопасности, за последние пять лет заметно увеличилось, федеральное законодательство содержит множество отсылочных норм. Данные обстоятельства обуславливают необходимость упорядочения рассмотренных требований, ограничений и запретов, и внесения изменений в соответствующий приказ Директора ФСБ России, касающихся всех требований, предъявляемых к сотрудникам органов безопасности. Ужесточение требований к кандидатам на военную службу является адекватной мерой для пополнения органов безопасности талантливыми, перспективными сотрудниками.

Мы предлагаем следующую классификацию требований при поступлении на военную службу:

- требования, предъявляемые к гражданам при поступлении на военную службу в военную организацию государства общего характера: гражданство; достижение определенного возраста; добровольного заключения контракта о прохождении военной службы;

\footnotetext{
${ }^{28} \mathrm{O}$ представлении информации, относящейся к обеспечению собственной безопасности органов федеральной службы безопасности, гражданами, поступающими на военную службу, на федеральную государственную гражданскую службу или на работу в органы федеральной службы безопасности» : приказ ФСБ России от 6 июля 2012 г. № 335 // Российская газета. -2012. - № 186. - 15 августа.
} 
DOI: $10.7256 / 1811-9018.2014 .8 .12547$

При цитировании этой статьи сноска на dоі обязательна

\section{Право и политика $8(176) \cdot 2014$}

прохождения испытательного срока, дактилоскопической регистрации; отсутствия судимости; требования, установленные статьей 33 Федерального закона «О воинской обязанности и военной службе» ${ }^{29}$, а также антикоррупционным законодательством;

- требования, предъявляемые к гражданам при поступлении на военную службу в органы безопасности: наличие соответствующих личных, профессиональных и психологических качеств; соответствие квалификационным требованиям к профессиональным знаниям и навыкам; соответствие требованиям в связи с обеспечением собственной безопасности ФСБ России; соответствие требованиям, установленным ч. 3 ст. 16 Федерального закона «О федеральной службе безопасности» ${ }^{30}$, а также приказом ФСБ России от 31 декабря 1999 г. № 714³.

\section{Библиография:}

1. О воинской обязанности и военной службе : федер. закон от 28 марта 1998 года № 53-Ф3 : принят Гос. Думой 6 марта 1998 г. : одобр. Советом Федерации 12 марта 1998 г. : в ред. федер. закона от 28 ноября 2009 г. № 286-Ф3 // Собр. законодательства Рос. Федерации. - 1998. - № 13. - Ст. 1475;

2. Вахидов А.Т. Организационно-правовые основы поступления граждан на военную службу по контракту в Вооруженных Силах Российской Федерации : дис. ...канд. юрид. наук. - М.: ВУ, 1996;

3. Чижикова О.Ю. Правовое регулирование поступления граждан на военную службу в пограничные органы федеральной службу безопасности : дис. ...канд. юрид. наук. - М.: Академия Управления МВД России, 2009;

4. О статусе военнослужащих : федер. закон от 27 мая 1998 г. № 76-Ф3 : принят Гос. Думой 6 марта 1998 г. : одобр. Сов. Федерации от 12 марта 1998 г. // Собр. законодательства Рос. Федерации. - 1998. - № 22.-Ст. 2331;

5. О противодействии коррупции : федер. закон от 25 декабря 2008 г. № 273-Ф3 : принят Гос. Думой от 19 декабря 2008 г. : одобр. Сов. Федерации

\footnotetext{
${ }^{29} \mathrm{O}$ воинской обязанности и военной службе : федер. закон от 28 марта 1998 г. № 53-Ф3 // Собр. законодательства Рос. Федерации. - 1998. - 13. - Ст. 1475;

${ }^{30} \mathrm{O}$ федеральной службы безопасности : федер. закон от 3 апреля 1995 г. № 40-Ф3 // Собр. законодательства Рос. Федерации. - 1995. - № 15. - Ст. 1269.

${ }^{31}$ О требованиях, предъявляемых к гражданам, поступающим на военную службу по контракту в органы федеральной службы безопасности : приказ ФСБ России от 31 декабря 1999 года № 714 // Российская газета - 2000. - № 33.
}

22 декабря 2008 г. : по состоянию на 28 декабря 2013 г.

// Собр. законодательства Рос. Федерации. - 2008. - № 52 (ч.1). - Ст. 6228;

6. О федеральной службе безопасности : федер. закон от 3 апреля 1995 г. № 40-Ф3 : принят Гос. Думой 22 февраля 1995 г. : по состоянию на 23 июня 2014 г. // Собр. законодательства Рос. Федерации. - 1995. - № 15. - Ст. 1269;

7. О внесении изменений в статьи 6 и 30 Федерального закона «О гражданстве Российской Федерации» и отдельные законодательные акты Российской Федерации : федер. закон от 4 июня 2014 г. № 142Ф3 : принят Гос. Думой 23 мая 2014 г. : одобрен Сов. Федерации 28 мая 2014 г. // Собр. законодательства Рос. Федерации. - 2014. - № 23. - Ст. 2927;

8. Конституция Российской Федерации : принята на всенародном голосовании 12 декабря 1993 г.: ч. 2 ст. 59 // Российская газета. - 1993. - 25 декабря;

9. Вопросы прохождения военной службы : указ Президента Российской Федерации от 16 сентября 1999 г. № 1237 // Собр. законодательства Рос. Федерации. - 1999. - № 38. - Ст. 4534;

10. О государственной дактилоскопической регистрации в Российской Федерации : федер. закон от 25 июля 1998 г. № 128-Ф3 : принят Гос. Думой 3 июля 1998 г. : одобр. Сов. Федерации 9 июля 1998 г.: по состоянию на 4 июня 2014 г. // Собр. законодательства Рос. Федерации. - 1998. - № 31. - Ст. 3806;

11. О внесении изменений в отдельные законодательные акты Россий-ской Федерации в связи с ратификацией Конвенции ООН против коррупции от 31 октября 2003 г. и Конвенции об уголовной ответственности за коррупцию от 27 января 1999 г. и принятием Федерального закона «О противодействии коррупции» : федер. закон от 25 декабря 2008 г. № 280Ф3 : принят Гос. Думой 19 декабря 2008 г. : одобр. Сов. Федерации 22 декабря 2008 г. // Собр. законодательства Рос. Федерации. - 2008. - № 52 (ч.1). - Ст. 6235;

12. О государственной гражданской службе Российской Федерации : федер. закон от 27 июля 2004 г. № 79-Ф3 : принят Гос. Думой 7 июля 2004 г. : одобр. Сов. Федерации 15 июля 2004 г. : по состоянию на 2 апреля 2014 г. // Собр. законодательства Рос. Федерации. - 2004. - № 31. - Ст. 3215;

13. О гражданстве Российской Федерации : федер. закон от 31 мая 2002 г. № 62-Ф3 : принят Гос. Думой 19 апреля 2002 г. : одобр. Сов. Федерации от 15 мая 2002 г. : по состоянию на 23июня 2014 г. // Собр. законодательства Рос. Федерации. - 2002. № 22. - Ст. 2031; 
14. Об утверждении Инструкции о порядке заключения в органах федеральной службы безопасности контрактов о прохождении военной службы с отдельными категориями граждан Российской Федерации: приказ ФСБ России от 27 июля 2009 г. № 357 // Российская газета. - 2009. - № 176. - 18 сентября;

15. Об утверждении Инструкции по организации и проведению профессионального психологического отбора в органах федеральной службы безопасности : приказ ФСБ России от 13 апреля 2011 г. № 151 // Бюллетень нормативных актов федеральных органов исполнительной власти. - 2011. - № 28;

16. Об утверждении Квалификационных требований к профессиональным знаниям и навыкам, необходимым для исполнения должностных обязанностей военнослужащими и федеральными государственными гражданскими служащими органов федеральной службы безопасности : приказ ФСБ России от 5 апреля 2010 г. № 159 // Бюллетень нормативных актов федеральных органов исполнительной власти. - 2010. - № 19;

17. Об организации военно-врачебной экспертизы в органах федеральной службы безопасности : приказ ФСБ России от 29 июня 2004 г. № 457 // Российская газета. - 2004. - № 206. - 21 сентября;

18. О требованиях, предъявляемых к гражданам, поступающим на военную службу по контракту в органы федеральной службы безопасности : приказ ФСБ России от 31 декабря 1999 года № 714 // Российская газета. - 2000. - № 33;

19. О представлении информации, относящейся к обеспечению собст-венной безопасности органов федеральной службы безопасности, гражданами, поступающими на военную службу, на федеральную государственную гражданскую службу или на работу в органы федеральной службы безопасности» : приказ ФСБ России от 6 июля 2012 г. № 335 // Российская газета. - 2012. - № 186. - 15 августа.

20. Анохин С.А., Герасимова О.А. Правовые качества сотрудников органов внутренних дел (полиции). // Полицейская деятельность. - 2011. - 1. - С. 20-25.

21. М.В. Костенников, А.В. Куракин, И.Н. Кошелев Административно-правовоерегулирование обеспечения собственной безопасности и противодействия коррупциив органах внутренних дел (ч. 1). // Административное и муниципальное право. - 2011. - 1. - С. 40-47.

22. Дейцева Н.А. Некоторые вопросы нормативноправового регулирования служебного поведения // Политика и Общество. - 2013. - 10. - С. 1192-1199. DOI: $10.7256 / 1812-8696.2013 .10 .5167$.
23. Пинчук П.В. О необходимости нормативно-правового регулирования государственной защиты экспертов государственных судебно-экспертных учреждений российской федерации // NB: Российское полицейское право. - 2014. - № 1. - C.125-134. DOI: 10.7256/2306-4218.2014.1.9911. URL: http://enotabene.ru/pm/article_9911.html

24. Комахин Б.Н. Информационное и инновационное общество и процесс развития государственной службы // NB: Административное право и практика администрирования. - 2014. - № 1. - С.32-45. DOI: 10.7256/2306-9945.2014.1.11155. URL: http://enotabene.ru/al/article_11155.html

25. Митрохин В.В.. Аттестация в механизме прохождения службы в органах внутренних дел // Полицейская деятельность. - 2013. - № 5. - С. 104 107. DOI: $10.7256 / 2222-1964.2013 .5 .10336$

26. Манойло А.В.. Технология реализации программы социальной адаптации военнослужащих // Национальная безопасность / nota bene. - 2013. - № 4 . - C. 104-107. DOI: 10.7256/2073-8560.2013.4.2401

27. Комахин Б.Н.. Административно-правовые направления повышения профессиональной деятельности государственных служащих // Административное и муниципальное право. - 2013. - № 7. - С. 104-107. DOI: 10.7256/1999-2807.2013.7.8953

28. Гатчин Ю.А., Ловлин А.Ю., Васильев Е.А. Модернизация автоматизированного программного комплекса тестирования государственных служащих // NB: Кибернетика и программирование. - 2013. - № 2. - C.29-35. DOI: 10.7256/2306-4196.2013.2.8306. URL: http://e-notabene.ru/kp/article_8306.html

29. В.Ю. Маркин. Порядок и особенности формирования кадрового состава судебных исполнителей после судебной реформы 1922 г. // Политика и Общество. -2013. - № 1. - C. 104-107. DOI: 10.7256/1812-8696.2013.01.13

30. Требенок А.А., Хандогина А.В.. К вопросу о международном сотрудничестве в области подготовки кадров правоохранительных органов // Полицейская деятельность. - 2013. - № 1. - С. 104107. DOI: 10.7256/2222-1964.2013.01.4

31. В.М. Пашин, А.А. Кобозев. Проблемы кадровой доктрины в системе МВД России // Административное и муниципальное право. - 2013. - № 1. - С. 104-107. DOI: $10.7256 / 1999-2807.2013 .01 .10$

32. Комахин Б.Н.. Административно-правовое и частно-правовое регулирование информационных и инновационных отношений в системе государственной службы // Административное и муниципальное право. - 2012. - № 7. - С. 104-107 


\section{Право и политика $8(176) \cdot 2014$}

33. Владимирова Т.В. О значении новых мобильностей для безопасности // NB: Национальная безопасность. 2014. - 1.-C. 9-23. DOI: 10.7256/2306-0417.2014.1.11164. URL: http://www.e-notabene.ru/nb/article_11164.html

34. Владимирова Т.В. Интенсивность коммуникаций практик новых мобильностей и информационная безопасность// NB: Проблемы общества и политики. -2014. - 1 . -C. 89 - 111. DOI: 10.7256/2306-0158.2014.1.10918. URL: http://www.e-notabene.ru/pr/article_10918.html

35. Владимирова Т.В. Проблема устойчивости порядка как угроза безопасности // NB: Национальная безопасность. -2013.-2.-C. 67-87.DOI: 10.7256/2306-0417.2013.2.590. URL: http://www.e-notabene.ru/nb/article_590.html

\section{References (transliteration):}

1. Vakhidov A.T. Organizatsionno-pravovye osnovy postupleniya grazhdan na voennuyu sluzhbu po kontraktu v Vooruzhennykh Silakh Rossiiskoi Federatsii : dis. ...kand. yurid. nauk. - M.: VU, 1996;

2. Chizhikova O.Yu. Pravovoe regulirovanie postupleniya grazhdan na voennuyu sluzhbu v pogranichnye organy federal'noi sluzhbu bezopasnosti : dis. ...kand. yurid. nauk. - M.: Akademiya Upravleniya MVD Rossii, 2009;

3. Anokhin S.A., Gerasimova O.A. Pravovye kachestva sotrudnikov organov vnutrennikh del (politsii). // Politseiskaya deyatel'nost'. - 2011. - 1. - C. 20-25.

4. M.V. Kostennikov, A.V. Kurakin, I.N. Koshelev Administrativno-pravovoe regulirovanie obespecheniya sobstvennoi bezopasnosti i protivodeistviya korruptsii v organakh vnutrennikh del (ch. 1). // Administrativnoe i munitsipal'noe pravo. - 2011. - 1. - C. 40-47.

5. Deitseva N.A. Nekotorye voprosy normativnopravovogo regulirovaniya sluzhebnogo povedeniya // Politika i Obshchestvo. - 2013. - 10. - C. 1192-1199. DOI: 10.7256/1812-8696.2013.10.5167.

6. Pinchuk P.V. O neobkhodimosti normativno-pravovogo regulirovaniya gosudarstvennoi zashchity ekspertov gosudarstvennykh sudebno-ekspertnykh uchrezhdenii rossiiskoi federatsii // NB: Rossiiskoe politseiskoe pravo. - 2014. - № 1. - S.125-134. DOI: 10.7256/23064218.2014.1.9911. URL: http://e-notabene.ru/pm/ article_9911.html

7. Komakhin B.N. Informatsionnoe $\mathrm{i}$ innovatsionnoe obshchestvo i protsess razvitiya gosudarstvennoi sluzhby // NB: Administrativnoe pravo i praktika administrirovaniya. - 2014. - № 1. - S.32-45. DOI: 10.7256/2306-9945.2014.1.11155. URL: http://e-notabene.ru/al/article_11155.html
8. Mitrokhin V.V.. Attestatsiya v mekhanizme prokhozhdeniya sluzhby v organakh vnutrennikh del // Politseiskaya deyatel'nost'. - 2013. - № 5. - S. 104-107. DOI: $10.7256 / 2222-1964.2013 .5 .10336$

9. Manoilo A.V.. Tekhnologiya realizatsii programmy sotsial'noi adaptatsii voennosluzhashchikh // Natsional'naya bezopasnost' / nota bene. - 2013. - № 4. - S. 104-107. DOI: 10.7256/2073-8560.2013.4.2401

10. Komakhin B.N.. Administrativno-pravovye napravleniya povysheniya professional'noi deyatel'nosti gosudarstvennykh sluzhashchikh // Administrativnoe i munitsipal'noe pravo. - 2013. - № 7. - S. 104-107. DOI: 10.7256/1999-2807.2013.7.8953

11. Gatchin Yu.A., Lovlin A.Yu., Vasil'ev E.A. Modernizatsiya avtomatizirovannogo programmnogo kompleksa testirovaniya gosudarstvennykh sluzhashchikh // NB: Kibernetika i programmirovanie. - 2013. № 2. - S.29-35. DOI: 10.7256/2306-4196.2013.2.8306. URL: http://e-notabene.ru/kp/article_8306.html

12. V.Yu. Markin. Poryadok i osobennosti formirovaniya kadrovogo sostava sudebnykh ispolnitelei posle sudebnoi reformy 1922 g. // Politika i Obshchestvo. - 2013. - № 1. - S. 104-107. DOI: 10.7256/1812-8696.2013.01.13

13. Trebenok A.A., Khandogina A.V.. K voprosu o mezhdunarodnom sotrudnichestve $\mathrm{v}$ oblasti podgotovki kadrov pravookhranitel'nykh organov // Politseiskaya deyatel'nost'. - 2013. - № 1. - S. 104-107. DOI: 10.7256/2222-1964.2013.01.4

14. V.M. Pashin, A.A. Kobozev. Problemy kadrovoi doktriny v sisteme MVD Rossii // Administrativnoe i munitsipal'noe pravo. - 2013. - № 1. - S. 104-107. DOI: $10.7256 / 1999-2807.2013 .01 .10$

15. Komakhin B.N.. Administrativno-pravovoe i chastno-pravovoe regulirovanie informatsionnykhi innovatsionnykh otnoshenii v sisteme gosudarstvennoi sluzhby // Administrativnoe i munitsipal'noe pravo. - 2012. - № 7. - S. 104-107

16. Vladimirova T.V. O znachenii novykh mobil'nostei dlya bezopasnosti // NB: Natsional'naya bezopasnost'. - 2014. - 1. - C. 9 - 23. DOI: 10.7256/2306-0417.2014.1.11164. URL: http://www.e-notabene.ru/nb/article_11164.html

17. Vladimirova T.V. Intensivnost' kommunikatsii praktik novykh mobil'nostei i informatsionnaya bezopasnost' // NB: Problemy obshchestva i politiki. - 2014. - 1. C. 89 - 111. DOI: 10.7256/2306-0158.2014.1.10918. URL: http://www.e-notabene.ru/pr/article_10918.html

18. Vladimirova T.V. Problema ustoichivosti poryadka kak ugroza bezopasnosti // NB: Natsional'naya bezopasnost'. - 2013. - 2. - C. 67 - 87. DOI: 10.7256/23060417.2013.2.590. URL: http://www.e-notabene.ru/nb/ article_590.html 